\title{
A NEW CICHLID TREMEMBICHTHYS GARCIAE (ACTINOPTERYGII, PERCIFORMES) FROM THE EOCENE-OLIGOCENE OF EASTERN BRAZIL
}

\author{
MARIA CLAUDIA MALABARBA \\ Museu de Ciências e Tecnologia, PUCRS, 90619-900, Porto Alegre, Brazil. mariacm@pucrs.br \\ LUIZ ROBERTO MALABARBA \\ Departamento de Zoologia, UFRGS, 90501-970, Porto Alegre, Brazil and MCT-PUCRS, Porto Alegre, Brazil. \\ malabarb@ufrgs.br
}

\begin{abstract}
The Aiuruoca Basin is located in the Mantiqueira Range and Alto Rio Grande Plateau, southern Minas Gerais State, Brazil. It includes two formations: Entre-Córregos, lacustrine facies, and Pinheirinho, alluvial fan facies. The specimen described here comes from the shales of the Entre-Córregos Formation, dated as Eocene-Oligocene. The phylogenetic analysis to establish its position within the Cichlidae was based on a matrix with 53 taxa (including two fossil taxa) and 91 characters. The fossil specimen preserved as part and counterpart, is assigned to a new cichlid species, Tremembichthys garciae sp. nov., as sister group of T. pauloensis in the Cichlasomatinae. The position of Tremembichthys within Cichlasomatinae is supported by infraorbitals with laminar expansion, the articulating process of the premaxilla moderately developed, and 13-14 pectoral-fin rays. The Neotropical cichlids resulted monophyletic and sister group of the Old World cichlids. Extant members of the family Cichlidae live mostly in lentic freshwater bodies, corroborating the lacustrine paleoenvironment assigned to this formation.
\end{abstract}

Key words: Cichlidae, phylogeny, Tremembichthys, Aiuruoca Basin, Tertiary, Tremembé Formation, Entre-Córregos Formation.

RESUMO - A bacia de Aiuruoca está localizada entre a Serra da Mantiqueira e o planalto do Alto Rio Grande, no sul de Minas Gerais, Brasil. A bacia inclui duas formações: Entre-Córregos, fácies lacustre e Pinheirinho, fácies de leques aluviais. O espécime descrito provém dos folhelhos da Formação Entre-Córregos, os quais são datados como Eoceno-Oligoceno. A análise filogenética para estabelecer sua posição dentro dos Cichlidae foi baseada numa matriz com 53 táxons (incluindo dois táxons fósseis) e 91 caracteres. O espécime fóssil preservado como molde e contramolde é atribuído a uma nova espécie, Tremembichthys garciae sp. nov., como grupo-irmão de T. pauloensis em Cichlasomatinae. A posição de Tremembichthys dentro de Cichlasomatinae é suportada por infraorbitais variadamente ossificados, processo articulatório da pré-maxila moderadamente desenvolvido; e 13-14 raios na nadadeira peitoral. Os ciclídeos neotropicais resultaram como um grupo monofilético e grupo-irmão dos táxons africanos. Os representantes viventes da família Cichlidae vivem principalmente em ambientes dulceaquícolas lênticos, corroborando o paleoambiente lacustre atribuído a esta formação.

Palavras-chave: Cichlidae, filogenia, Tremembichthys, bacia de Aiuruoca, Terciário, Formação Tremembé, Formação EntreCórregos.

\section{INTRODUCTION}

The Aiuruoca Tertiary Basin is located in southern Minas Gerais State (southeastern Brazil) between the Mantiqueira Mountain Range and southern border of the Minduri Range, in the Alto Rio Grande Plateau. This basin, bounded by the coordinates $44^{\circ} 15^{\prime} \mathrm{W}-44^{\circ} 45^{\prime} \mathrm{W}$ and $22^{\circ} 15^{\prime} \mathrm{S}-21^{\circ} 30^{\prime} \mathrm{S}$ (Figure 1), has a complex morphotectonic framework which resulted from two tectonic events occurring in the Paleogene and Neogene-Quartenary (Santos et al., 1999, 2006). The basin is drained by the Aiuruoca River, which crosses the area in a northward direction. The sediments filling up this basin are recognized as the Aiuruoca Group (Santos, 1999; Santos et al., 1999) with two formations: Pinheirinho (alluvial fan) and Entre-Córregos (lacustrine). The Entre-Córregos Formation is constituted by mudstone sediments as dark gray shales intercalated with clays. The sequence of the beds and the palynological content suggests that the sediments were deposited in a lacustrine environment during the EoceneOligocene age (Garcia et al., 2000; Oliveira et al., 2006).

Fieldwork carried out by the Laboratório de Geociências of the Universidade de Guarulhos (São Paulo State) found a small outcrop characterized by a remarkable concentration of fossils. The fossil content of the Entre-Córregos Formation includes plants, palynomorphs, insects and vertebrates (Garcia et al., 2000; Bedani \& Haddad, 2002; Delgado \& 

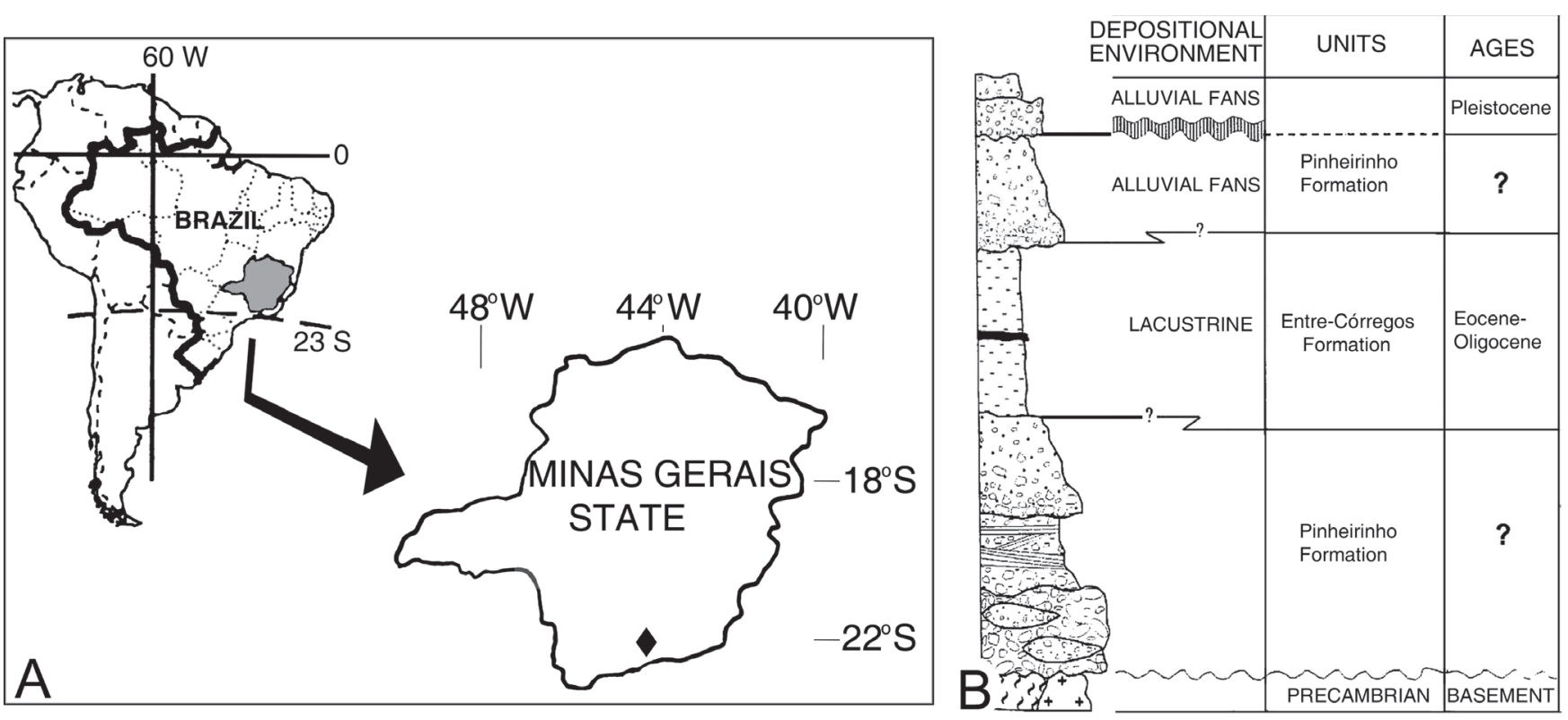

Figure 1. Location map of the collecting site: A, outcrop location (diamond) in southern Minas Gerais State, eastern Brazil. B, geological column of the sedimentary deposits of the Aiuruoca Basin (modified from Santos, 1999).

Oliveira, 2004). The amphibians are represented by dozens of anuran specimens in an excellent state of preservation (Bedani \& Haddad, 2002). The paleoichthyofauna is formed by specimens belonging to the families Cichlidae and Characidae, most of them complete and articulated, besides several young and small undetermined individuals (Malabarba, 2004). The cichlid material is represented by one complete specimen with part and counterpart.

Cichlids are teleost fishes found chiefly in freshwaters. They represent one of the major vertebrate families with at least 1300 species (Kullander, 1998) and are among the most specious percoid families. Despite this fact, the cichlid fossil record is poor, limited to some few species in Africa, Europe, Central and South America, and the Near East. In South America, fossil cichlids are recorded for the OligoceneMiocene of Brazil and the Miocene and Eocene of Argentina (Arratia \& Cione, 1996; Malabarba et al., 2006). This paper deals with the description of a new cichlid species from the Aiuruoca Basin assigned to the genus Tremembichthys Silva Santos \& Santos, 1993.

The monotypic genus Tremembichthys was erected to include Aequidens pauloensis (Schaeffer, 1947) described from the lacustrine shales of the Tremembé Formation, Taubaté Basin, in southeastern Brazil. Geological and paleontological studies of this basin have associated its origin and evolution with the opening of the Atlantic Ocean and dated the sediments of the Tremembé Formation as Oligocene-Miocene (Lima et al., 1985; Lundberg et al., 1998; Riccomini et al., 2004; Soria \& Alvarenga, 1989). In an abstract, Silva Santos \& Oliveira (1974) suggested the inclusion of this species in the genus Geophagus, apparently based on the modern nature of the fossil. Later, Silva Santos \& Santos (1993) redescribed the species in a new genus, Tremembichthys. As this redescription did not provide a genus diagnosis, we present here a diagnosis for the genus Tremembichthys.

\section{MATERIAL AND METHODS}

The study material is a sole individual preserved as an impression with part and counterpart (Figure 2). It was collected by the team from the Earth Sciences Laboratory at the Universidade de Guarulhos in the lacustrine shales of the Entre-Córregos Formation, Aiuruoca Tertiary Basin (Figure 1). The preparation involved just a slight cleaning with brush under a microscope. Latex peels were made for the fossil part and counterpart. Anatomical illustrations were prepared from sketches of structures as viewed with a camera lucida. Photographs were taken using a digital Nikon camera mounted on a microscope. For emphasizing the described structures, the fossil and latex peels were sprinkled with ammonium chloride $\left(\mathrm{NH}_{4} \mathrm{Cl}\right)$.

The morphometric data (Table 1) were taken following Reis \& Malabarba (1988) for the general head and body measurements, except for caudal peduncle length which is defined here as the end of the anal-fin base to the vertebrahypural junction. In the counts of fin rays, upper-case Roman numerals indicate spines, and Arabic numerals indicate soft rays. Jaw measurements and nomenclature follow Casciotta \& Arratia (1993a), including the coulter area term employed in the description, which refers to the lower jaw area formed by the retroarticular and by the canal-bearing ventral portion of the anguloarticular.

Material examined. Macracara prisca, DGM 22-P, syntype, a complete specimen. Proterocara argentina, CNS-V10020, holotype, complete specimen preserved as part and counterpart. Tremembichthys pauloensis, UnG T-006, UnG T-001, and DBAV 214-Pz, articulated specimens. 

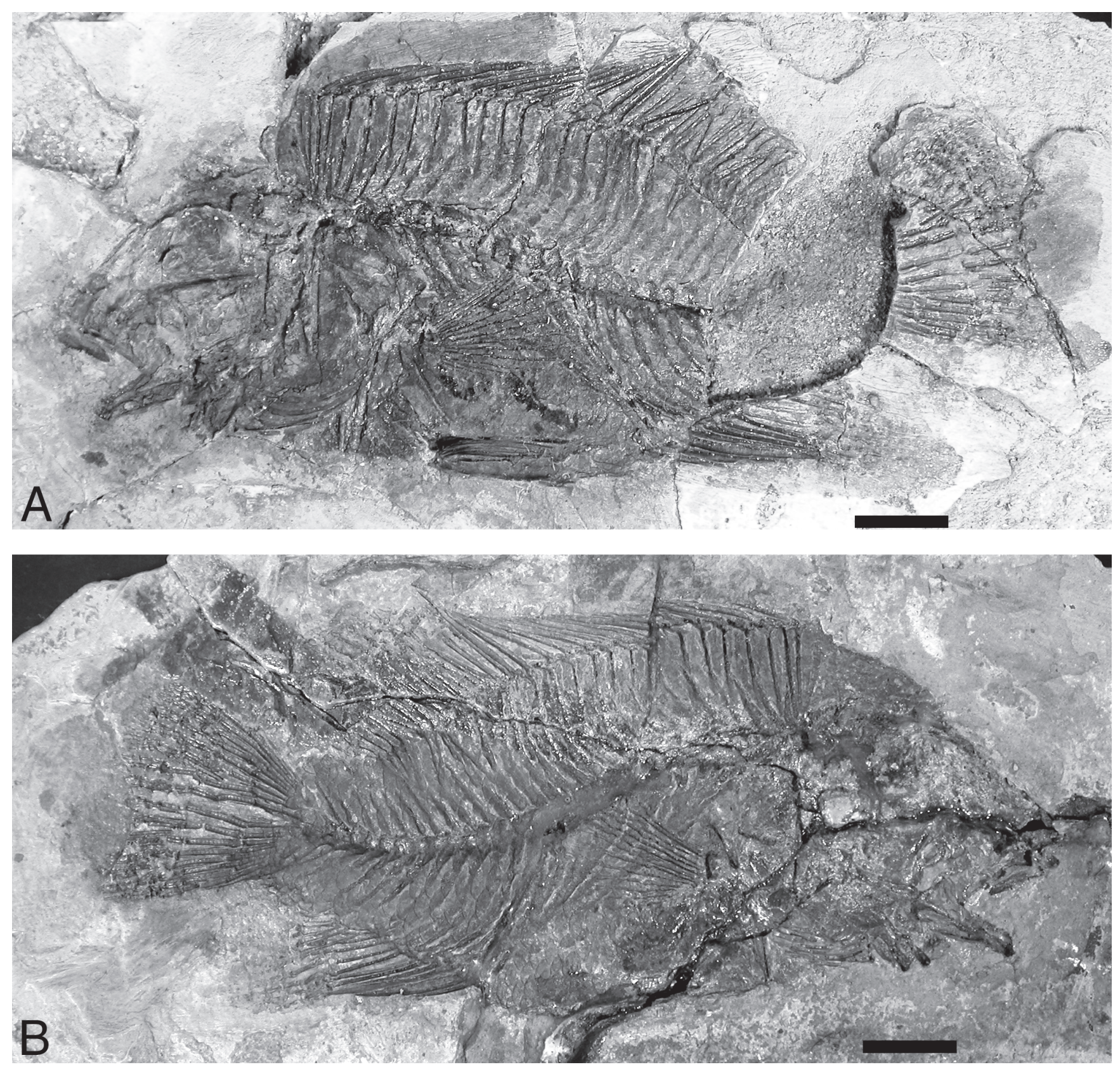

Figure 2. Tremembichthys garciae n. sp., UNG 2T-148, with part (A) and counterpart (B). Scale bar $=1 \mathrm{~cm}$.

\section{Abbreviations}

Institutional abbreviations. CNS-V, Collection of Paleontology, Facultad de Ciencias Naturales, Universidad Nacional de Salta, Salta; DBAV, Departamento de Biologia, da Universidade do Estado do Rio de Janeiro, Rio de Janeiro; DGM-P, Departamento Nacional de Produção Mineral, Rio de Janeiro; UNG, Universidade de Guarulhos, Guarulhos.

Anatomical abbreviations. Aa, anguloarticular; AAD, anguloarticular depth; AAL, anguloarticular length; Btr, branchiostegal rays; CAD, coulter area depth; CAW, coulter area width; Cl, cleithrum; De, dentary; Dpc, distal postcleithrum; Fo, lateral line foramina; HL, head length; La, lachrymal; Mx, maxilla; Op, opercle; Pa, palatine; Pc, pectoral fin; Pds, predorsal scales; Pm, premaxilla; Pp, primordial process; $\mathbf{P q}$, anguloarticular postarticular process that articulates with the quadrate; Ps, parasphenoid; Pv, pelvic fin; Q, quadrate; Ra, retroarticular; Rd, radials; $\mathbf{R y ,}$ rays; Sc, scapula; Scl, supracleithrum; SL, standard length; Sn, supraneural; Sop, subopercle; Spo, supraoccipital crest; Vo, vomer.

\section{Cladistic methodology}

The phylogenetic position of the new fossil species is discussed based on the matrix presented by Kullander (1998), which consists of 53 taxa (including 2 fossil taxa) and 91 characters. Tremembichthys pauloensis and the new species were added to this matrix in the MacClade program 


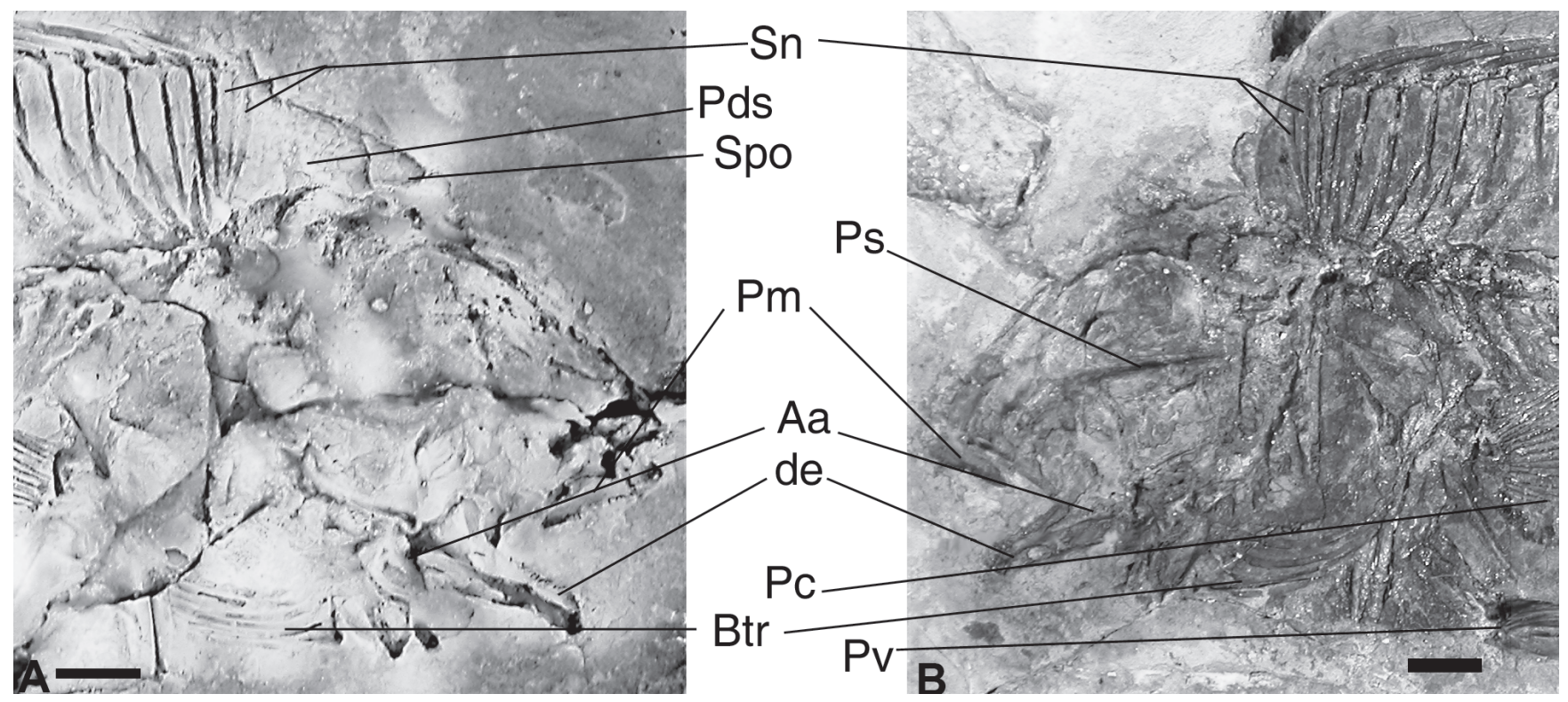

Figure 3. Anterior region of Tremembichthys garciae n. sp., UNG 2T-148: A, the fish sprinkled with ammonium chloride; B, counterpart. Scale bars $=5 \mathrm{~mm}$.

and analyzed on a Macintosh computer using PAUP 3.1 (Swofford, 1993) in a heuristic branch-swapping searching (ACCTRAN optimization, unordered characters). Data referring to $T$. pauloensis were scored based on those obtained from the specimens examined (UnG-T 006, UnG-T 001, and DBAV 214-Pz) and the data presented in the redescription (Silva Santos \& Santos, 1993). In the Appendix is listed the character states scored for the fossil species in the matrix. One thousand and two hundred trees resulted from this analysis, and the characters were weighted using the rescaled consistency index. A new search was thus performed based on these 1200 trees with those weights applied, producing a single tree.

\section{SYSTEMATIC PALEONTOLOGY}

\section{PERCIFORMES \\ LABROIDEI \\ CICHLIDAE \\ CICHLASOMATINI}

Tremembichthys Silva Santos \& Santos, 1993

Diagnosis. Tremembichthys is a deep-bodied cichlid with two supraneurals; an ascending arm of premaxilla longer than dentigerous one with articulating process moderately differentiated; jaw teeth unicuspids; preopercular scales absent; pectoral-fin rays, 13-14; dorsal-fin spines 15; total anal fin count 15 or less; anal-fin spines 4 or less; hemal arch supporting three to four first anal-fin pterygiophores; caudal fin truncate-subtruncate; three dorsal procurrent caudal-fin rays; at least one complete and one half centrum contained within the caudal peduncle; abdominal vertebra 13-15, the number of caudal vertebrae equal or higher; last pleural rib on the last or penultimate abdominal vertebra; first hemal arch on the first caudal vertebra.
Tremembichthys garciae $\mathrm{n}$. sp.

(Figures 2-6, Table 1)

Diagnosis. Tremembichthys garciae can be distinguished from other cichlids by the following combination of characters: a slender maxillary process of the palatine; four lateralis canal openings in the dentary; maxillary process of the palatine cylindrical; abdominal vertebrae 15 , caudal vertebrae 16 ; dorsal-fin rays, $\mathrm{XV}+14$; three pterygiophores articulating with the first hemal arch; pelvic fin pointed; and a caudal peduncle deeper than long.

Holotype and only specimen. UNG 2T-148, a complete specimen preserved as part and counterpart (Figure 2).

Type-locality. Margins of Entre-Córregos Stream, about 15 $\mathrm{km}$ northwest of the town Aiuruoca in southern Minas Gerais State, Brazil.

Horizon and age. Entre-Córregos Formation, Aiuruoca Tertiary Basin, Eocene-Oligocene.

Etymology. Specific name in honor of Maria Judite Garcia in recognition of her active contribution to Brazilian paleontology.

\section{Description}

Measurements of $T$. garciae n. sp. are given in Table 1. UNG 2T-148 is preserved as an impression (part and counterpart) of a whole individual in lateral view (Figure 2). Tremembichthys garciae is a deep-bodied cichlid reaching $90 \mathrm{~mm}$ in standard length and $112 \mathrm{~mm}$ in total length. The greatest body depth $(43.10 \% \mathrm{SL})$ is located at the origin of dorsal fin. The head is deep, its maximum depth is slightly smaller than the greatest body depth. The dorsal profile of the head is steep from the upper jaw to the supraoccipital. Dorsal profile of body convex from supraoccipital crest to caudal peduncle and straight along the caudal peduncle. Ventral profile of body gently curved from lower jaw to caudal peduncle and straight along the caudal peduncle. The caudal 

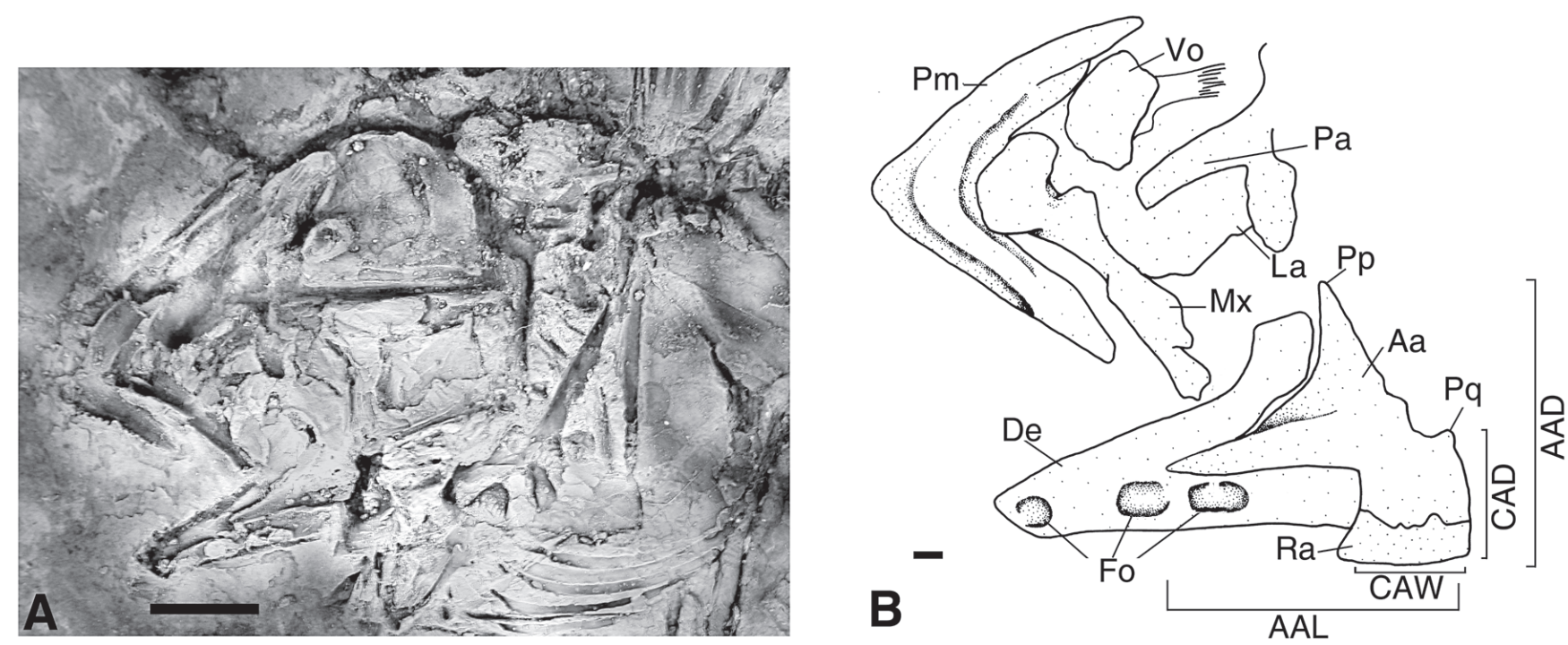

Figure 4. Tremembichthys garciae n. sp., UNG 2T-148: A, anterior region of head sprinkled with ammonium chloride, scale bar = $5 \mathrm{~mm}$; $\mathbf{B}$, drawing of the upper and lower jaw regions, scale bar $=1 \mathrm{~mm}$.

peduncle is short, deeper $(17.6 \% \mathrm{SL})$ than long $(10 \% \mathrm{SL})$.

Skull. Most of the skull is crushed, the bones being partly disarticulated and fragmented (Figure 3, 4). Some of them are just complete enough to be identified, but their shape cannot be accurately determined. That is the case for the upper pharyngeal jaws. Fragments of the tooth plates of the pharyngobranchials 3 and 4 are preserved with alveoli and few scattered bicuspid teeth, but the presence and number of frayed zones cannot be defined with certainty.

The vomerine tip is expanded and robust with no notch. The suture between the vomer and parasphenoid is interdigitating. The maxillary process of the palatine is cylindrical and slender.

The circumorbital bones are also badly preserved and too little can be seen from this region. Only two rami of the lateralis canal can be recognized in the lachrymal; although it seems to have a square outline, its shape (character 40) was not informed in the matrix. The most anterior region of this bone is concealed by the vomer head and palatine. The next infraorbital in series (Infraorbital 2) is near rectangular bearing a canal, which seems to contact the lachrymal. The other infraorbitals from the series cannot be recognized.

Jaws. Premaxilla has the ascending arm longer than the dentigerous one. The ascending arm is wider with a somewhat distinct articular process whose dorsal apex is close to the ascending process. The angle formed by the confluence between the ascending and dentigerous arm is about $90^{\circ}$, not projecting rostrad at the symphysis. The dentigerous arm is straight, tapering in the direction of the caudal end with no process in the dorsal margin (see Casciotta \& Arratia, 1993a). The impressions of alveoli and some tooth casts indicate that simple unicuspid teeth were distributed in a row all over the entire oral border of the dentigerous ramus. The maxilla is long, nearly straight, with a moderate dorsal process. Anteriorly, a well-developed articulating head is discreetly separated from the shaft.
The lower jaw is short and high (Figure 3). The mandibular sensory canal runs enclosed along the ventral region of this bone. Four foramina are present in the dentary: two anteriormost near symphysis; a large one in the middle part of the dentary; and a caudalmost foramen in the end of the canal facing the rostrad foramen of the anguloarticular (this opening in the rear of the dentary is not clearly seen in the fossil). The anguloarticular is slightly deeper than long (Figures 3,4A), with a triangular, directed dorsad primordial process. The coulter area is almost as wide $(4.35 \mathrm{~mm})$ as deep

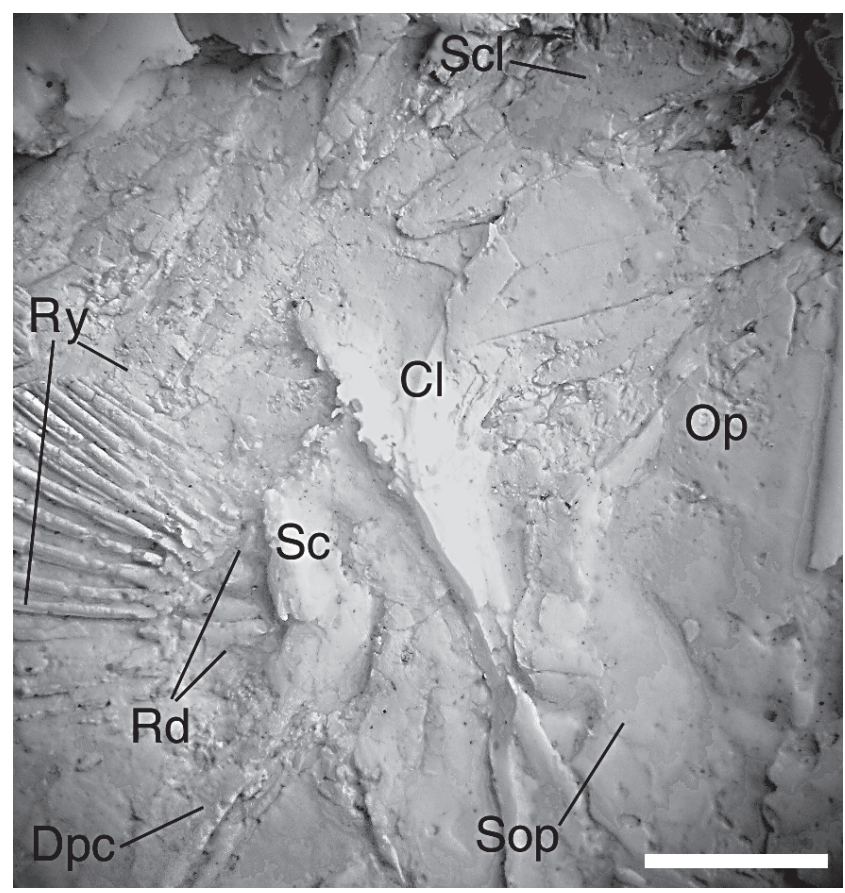

Figure 5. Tremembichthys garciae n. sp., UNG 2T-148. A latex peel sprinkled with ammonium chloride showing part of pectoral fin and girdle. Scale bar $=5 \mathrm{~mm}$. 

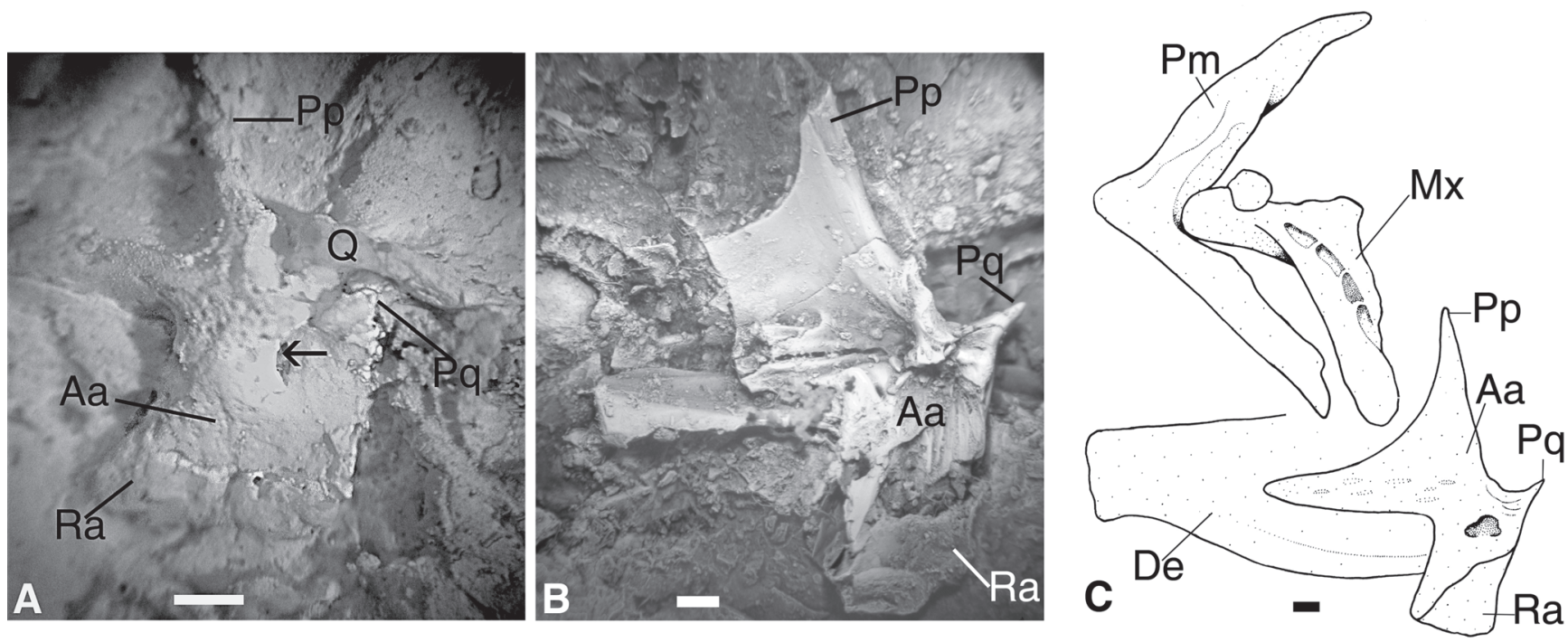

Figura 6. Jaws in Tremembichthys: A, T. garciae n. sp., UNG 2 T-148, coulter area in lateral view indicating (arrow) the course of the sensory canal in the anguloarticular (latex peel with ammonium chloride). B-C, T. pauloensis, UNG T-006, fossil specimen with ammonium chloride showing coulter area in mesial view (B) and interpretative drawing of the mandibles in lateral view (C). Scale bars $=1 \mathrm{~mm}$.

(4.5 mm), assuming a square-like shape; the mandibular canal of the anguloarticular crosses it obliquely. The caudal margin of the coulter area is slightly curved; the ventral margin is nearly straight, all formed by the retroarticular. Some impressions of conical and small $(0.5 \mathrm{~mm})$ teeth can be seen in the dentigerous (dorsal) margin of the dentary.

Paired fins. The pectoral girdle is almost completely preserved. The cleithrum is elongate and curved with a lamellar posterior projection. The ventral end is spiniform and the dorsal process is concealed by the large supracleithrum. Part of a proximal postcleithrum is visible below the lamellar part of the cleithrum. The distal postcleithrum is long and styliform; it is ventroposteriorly directed from the pectoral-fin insertion. Only a small square fragment of the scapula was preserved. There are four bar-like proximal radials; the two ventralmost radials are longer than the dorsal ones. The coracoid is preserved behind the ventral part of the cleithrum; it is a triangular plate with a notch in the middle part.

The pectoral fin (Figure 5) has 13-14 rays; dorsalmost and ventralmost rays are shorter than the other ones giving a rounded shape to this fin.

The pelvic plate is anteriorly tapered and expanded posteriorly, assuming a triangular shape. It is not possible to verify the presence of a postpelvic process due to the condition of preservation. Pelvic-fin rays I, 5; all fin spines, dorsal, pelvic and anal, have smooth surfaces.

Dorsal and anal fins. The dorsal and anal fins are completely preserved. The dorsal-fin origin is separated from the supraoccipital crest by two supraneurals. There are 15 spines and 14 soft rays in the dorsal fin; spiny and soft dorsal-fin portions are continuous with no gap between them. The anteriormost spines increase in length slightly to $6^{\text {th }}$ ray; from $7^{\text {th }}$ to $15^{\text {th }}$ they have about the same size. They are followed by 14 segmented rays which are longer than the spines. Twenty-nine pterygiophores are present, all of them reaching the neural spines of vertebrae except the 5-6 posterior ones.
The proximal end of the pterygiophore is expanded in an articular facet, slightly concave, to fit the ray condyle. The two supraneurals are parallel, similar in size and the ventral ends contact the neural spine of the first vertebrae.

The anal-fin rays III +9; the longest rays reach the half of the caudal fin. There are 11 pterygiophores; the first one supports the two anteriormost fin spines. The first three pterygiophores articulate with the hemal spine of the first caudal vertebra. The anal-fin spines increase in length posteriorly; the third one is the longest. The branched rays increase in length up to third one, which is the longest branched ray, and then they gradually diminish in size.

Caudal fin. The caudal peduncle seems to contain one or two complete centra plus the last half-centrum. The ural complex cannot be observed in any of the specimens, because preservation of the scales conceals the skeleton. The caudal fin has a slightly rounded posterior margin $_{2}$ and it is made up of 16 ( 8 dorsal +8 ventral) principal rays. A short prolongation (about five scales) of the lateral line tube into proximal third of the caudal fin is visible between the ventral and dorsal lobes.

Vertebral column. Most of the vertebra morphology is concealed by the scaling impression. However, it is possible to figure out vertebral counts through the neural spine and vertebra impressions. A total of 31 vertebrae are counted for T. garciae, of which 15 abdominal and 16 caudal. The last pleural rib is connected to the vertebra 14 ; the $16^{\text {th }}$ vertebra bears a hemal spine, the tip of which articulates with the first two anal pterygiophores.

Squamation. The scales are mostly large $(3.8 \mathrm{~mm})$ and ctenoid all over the body. In the opercle there are large and small cycloid scales scattered mainly on the dorsal and posterior portions of the bone. Interopercular with 4 scales in a single row with the posteriormost scale the largest, reducing in size gradually rostrad. There is no evidence of scales in preopercular. Some rows of small cycloid scales are present 
Table 1. Measurements of the holotype of T. garciae (UNG 2T148) and a specimen of T. pauloensis (UNG T-006).

\begin{tabular}{|c|c|c|}
\hline Character & $\begin{array}{c}T . \\
\text { garciae } \\
\text { holotype }\end{array}$ & $\begin{array}{c}T . \\
\text { pauloensis } \\
\text { UNG T-006 }\end{array}$ \\
\hline Standard length (mm) & 90.38 & 145.08 \\
\hline \multicolumn{3}{|c|}{ Percents of standard length } \\
\hline Bony head length & 40.93 & 36.22 \\
\hline Bony head depth & 42.19 & 44.50 \\
\hline Snout to anal-fin origin & 78.55 & 74.38 \\
\hline Snout to pelvic-fin origin & 50.76 & 47.74 \\
\hline Anal-fin base length & 17.44 & 17.23 \\
\hline Caudal peduncle length & 12.13 & 14.63 \\
\hline Caudal peduncle depth & 19.42 & 15.72 \\
\hline Body depth at dorsal-fin origin & 47.70 & 47.31 \\
\hline Pectoral-fin length & 26.98 & \\
\hline \multicolumn{3}{|c|}{ Percents of head length } \\
\hline Snout length & 37.59 & 47.48 \\
\hline Premaxilla ascending ramus width & 5.32 & 6.54 \\
\hline Premaxilla ascending ramus length & 27.62 & 30.34 \\
\hline Premaxilla dentigerous ramus length & 22.97 & 27.66 \\
\hline Coulter area width & 11.05 & 7.64 \\
\hline Coulter area depth & 16.43 & 15.67 \\
\hline Angulo-articular length & 25.21 & 21.57 \\
\hline Angulo-articular depth & 21.72 & 23.15 \\
\hline Horizontal eye diameter & 26.86 & \\
\hline \multicolumn{3}{|l|}{ Countings } \\
\hline Anal-fin spines & 3 & 3 \\
\hline Anal-fin rays & 9 & 9 \\
\hline Dorsal-fin spines & 15 & 14 \\
\hline Dorsal-fin rays & 16 & 12 \\
\hline Pectoral-fin rays & $13-14$ & \\
\hline Abdominal vertebrae & 15 & 13 \\
\hline Caudal vertebrae & 16 & 16 \\
\hline
\end{tabular}

on the predorsal region. In the caudal fin, cycloid scales cover the proximal third of the fin between adjacent rays. Small cycloid scales fully cover the occiput and the prepelvic region.

The specimen UNG 2T-148 preserves the complete lateral line. The upper lateral line begins just at the posterodorsal edge of the opercle and continues going up and along the body until the $7^{\text {th }}$ branched dorsal-fin ray (about $17^{\text {th }}$ vertebra). There are two scale rows between the upper lateral line and the dorsal fin. The lower lateral line segment continues from about this point, but very near the vertebral column, entering in the middle of the caudal fin base, in the gap between the dorsal and ventral caudal-fin rays.

\section{COMPARISON WITH OTHER FOSSIL CICHLIDS}

Cichlids have a notably poor fossil record considering their recent diversity. Among the few records of fossil cichlids, just five are assigned to the South American sediments: Proterocara argentina Malabarba et al., 2006; Tremembichthys pauloensis (Schaeffer, 1947) from OligoceneMiocene of Brazil; Aequidens saltensis Bardack and Paleocichla longirostrum (Bardack, 1961) from Miocene of Argentina (Casciotta \& Arratia, 1993b); and Macracara prisca Woodward, 1939 from Pliocene of Brazil.

Proterocara argentina was recently described (Malabarba et al., 2006) from the Lumbrera Formation, Eocene of Argentina. This basal neotropical cichlid can be easily distinguished from $T$. garciae by the number of vertebrae (9 abdominal +19 caudal vertebrae versus 15 abdominal +16 caudal in $T$. garciae) and dorsal-fin rays (XI $+12-13$ versus $\mathrm{XV}+14$ in $T$. garciae).

Aequidens saltensis and Acaronia longirostrum were described by Bardack (1961) for the sediments cropping out in the vicinities of Salta, Miocene of Argentina. According to information from Casciotta \& Arratia (1993b:199), the type materials of both species were lost. Although the description and illustrations provided by Bardack (1961) still do not allow a detailed comparison, $A$. saltensis can be differentiated from T. garciae by having fewer vertebrae (27-28 versus 31 in $T$. garciae) and a smaller number of dorsal-fin rays (XIII +13 versus XV + 14 in T. garciae). Kullander (1983:318) suggested possible geophagine relationships for $A$. saltensis.

Casciotta \& Arratia (1993b) transferred Acaronia longirostrum to the genus Palaeocichla, and based on a phylogenetic analysis of the American cichlids, involving fossil and recent forms, suggested a sister-group relationship between Paleocichla and Cichla. Palaeocichla longirostrum can be distinguished from $T$. garciae by its more elongated body, much longer caudal peduncle and shape of the dorsal fin with posterior spines decreasing in size. A coulter area longer than deep with a long, acute and anteriorly projected rostral margin differs from $T$. garciae in which the coulter area is square in shape and with no projection of the rostral margin (Figures 2,3).

Macracara prisca Woodward, 1939 was described for lacustrine shales, known as Nova Yorque Beds, exposed on the bank of the Parnaíba River near Nova Yorque village. Palynologic analyses (Lima, 1991; Dino et al., 2006) have assigned a Pliocene age for these beds which would have been deposited in an abandoned meander of the Parnaíba River. The examination of the Macracara sintype (DGM 22$\mathrm{P})$ revealed that it can be distinguished from $T$. garciae by its higher number of vertebrae (36 as opposed to 31 in $T$. garciae); a smaller number of dorsal-fin soft rays (10 versus 14 in $T$. garciae); a smaller number of pectoral-fin rays (10 versus 13 14 in $T$. garciae); and a more posterior-located orbit which gives it a longer snout (40\% HL versus $37 \% \mathrm{HL}$ in $T$. garciae).

Tremembichthys pauloensis is the cichlid record geographically nearest to $T$. garciae, and also, both formations, Tremembé and Entre-Córregos, are made up of thin dark shales deposited in a lacustrine environment. Tremembichthys pauloensis agrees with T. garciae in counts of supraneurals, vertebrae, rays of pectoral and anal fins, besides morphometric parameters such as body depth, head depth, anal-fin base length and width of premaxilla ascending arm. The differences between the two species rely mainly on the number of dorsal-fin soft rays (12 versus 14 in T. garciae); length of premaxilla dentigerous arm $(27.6 \% \mathrm{HL}$ versus $22.9 \%$ HL in T. garciae) and several aspects of the lower jaw. The coulter area in $T$. garciae is square in shape (as deep as wide) with a rectangular retroarticular occupying its ventral region. In T. pauloensis, the coulter area is deeper than wide, rectangular in shape, and the retroarticular is triangular, forming almost the entire ventral and posterior borders of 


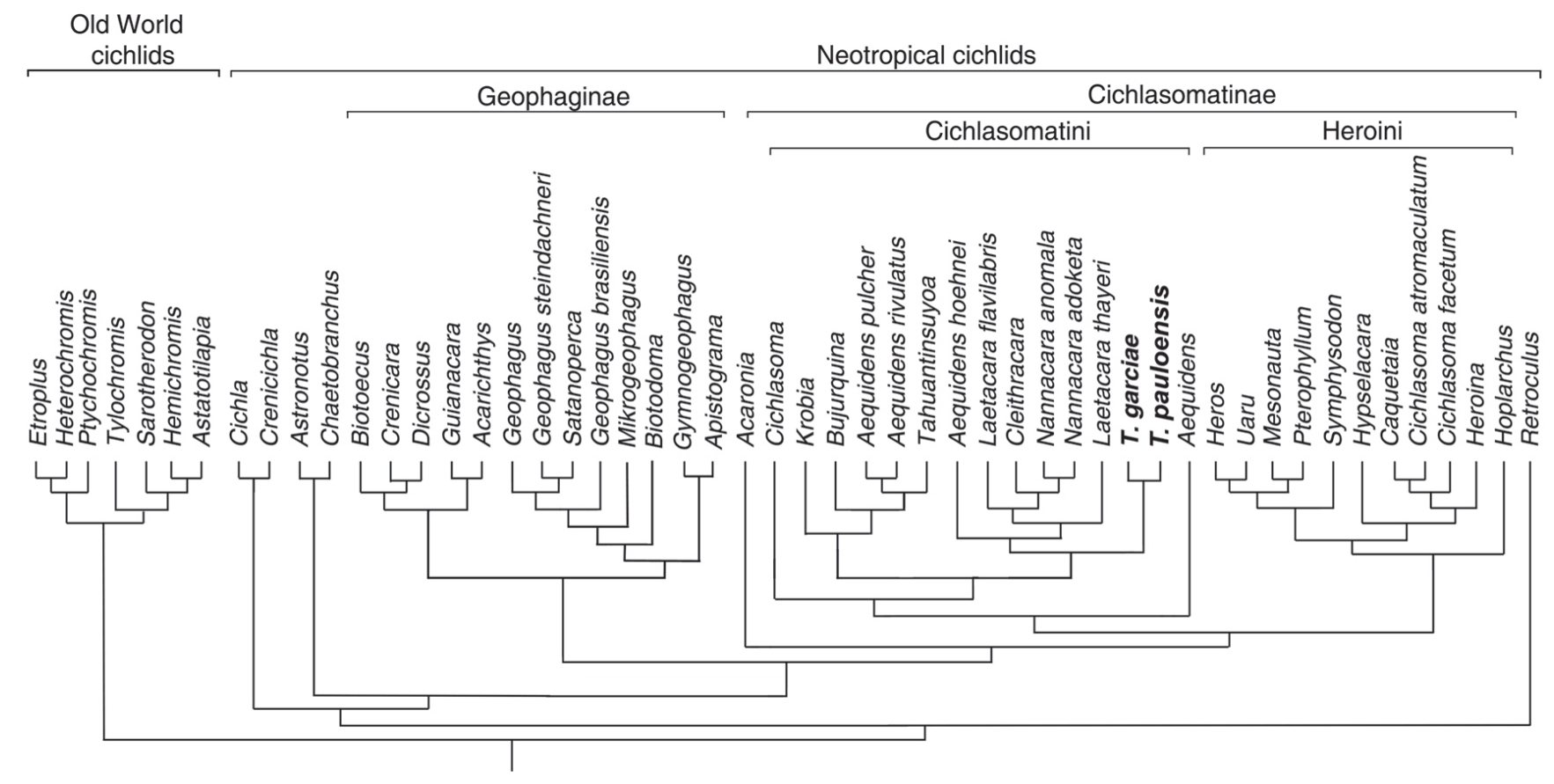

Figure 7. Parsimonious tree (607 steps, $\mathrm{Cl} 0.36$, RI 0.67 , RC 0.24 ) obtained from a successive weighting analysis. Based on data matrix of Kullander (1998).

this area. Besides, the coulter area of T. pauloensis bears an acute postarticular process adjacent to the articular facet for the quadrate (Figure 4). This process is blunt in $T$. garciae. We consider these differences consistent with the recognition of two species.

\section{PHYLOGENETICS ANALYSIS}

The phylogenetic position of Tremembichthys garciae within Cichlidae was evaluated based on the matrix presented by Kullander (1998). The two fossil taxa, T. pauloensis and $T$. garciae, were added to Kullander's matrix, which was analyzed using PAUP 3.1 with heuristic branch-swapping search and ACCTRAN optimization. This procedure resulted in 1200 minimum length trees (606 steps, CI 0.25, RI 0.56, RC 0.14). Weighting according to rescaled consistency index (base weight:1000) was then applied to the characters and a new search was performed on the basis of these 1200 heuristic trees. A single tree was thereby produced with 607 steps, CI 0.367 , RI 0.678 , RC 0.249 , assigning both fossil species of Tremembichthys to a single clade within the cichlasomatini (Figure 7).

The obtained tree (Figure 7) is basically the same proposed by Kullander (1998). The four major lineages, the Old World cichlids, the geophagines, the cichlasomes and the heroines, are still recognized as monophyletic. Composition and relationships of these groups were retained with Retroculus as the sister group of the remaining Neotropical cichlids. The most noticeable change is the recovering of Heterochromis within the Etroplinae sensu Kullander (1998), forming a larger basal group along with the Pseudocrenilabrinae (Tylochromis, Hemichromis, Sarotherodon and Astatotilapia). In the analysis of Kullander (1998), Heterochromis multidens, a monotypic African taxon, resulted nested among the Neotropical cichlids. According to Chakrabarty (2004), this could be due to Heterochromis being a taxon difficult to code, and its inclusion repeatedly results in paraphyletic groups in Gondwanan fragments (see Chakrabarty, 2004 for a detailed discussion). In the analysis performed here, Heterochromis is grouped with Etroplus of India and Ptychochromis of Madagascar, and the Neotropical lineage is monophyletic and sister group of the Old world cichlids.

Despite these differences, the three major neotropical groups (Geophagini, Heroini and Cichlasomatini) recognized in the Kullander's proposition are maintained with the addition of Tremembichthys. Of the nine synapomorphies grouping the Neotropical cichlids, only two could be observed in $T$. garciae: an interdigitating suture between the vomerine shaft and the parasphenoid bar (character 37, state1) and an ascending arm of premaxilla longer than dentigerous one (character 64, state 2, the general condition among the American cichlids according to Casciotta \& Arratia, 1993a). The interdigitating vomerine suture was considered as diagnostic for Neotropical taxa in the analysis of Stiassny (1991). Two of the 9 synapomorphies of Neotropical cichlids are absent, and the remaining 5 were not preserved in $T$. garciae. Besides, its inclusion among the New World cichlids is corroborated by the presence of synapomorphies defined at different levels within Neotropical cichlids, such as: the first hemal arch on the first caudal vertebra (character 70) defined for New World cichlids above Retroculus; maxillary process of the palatine cylindrical and slender (Character 51, state 0 ), caudal fin truncate-subtruncate (character 83, state 1 ); three procurrent caudal-fin rays (character 84 , state 1 ), 
and pelvic fin pointed (character 86, state 1), defined for Neotropical World cichlids above Cichlinae (Cichla + Crenicichla).

Tremembichthys garciae shows four synapomorphies of the seven ones supporting the clade Cichlasomatinae in this analysis: two anterior infraorbitals with laminar expansion (character 43, state 1); dentary lateralis canal openings reduced from five to four (character 45, state 1); articulating process moderately differentiated (character 63, state 1); and 13-14 pectoral-fin rays (character 85, state 2). Only the second synapomorphy (character $45,0>1$ ) is an unambiguous change, occurring in all trees. The other three synapomorphies defined for this node (characters 3, 8, 20) were not preserved and they were assumed to be present in $T$. garciae by parsimony.

The tribe Cichlasomatini is defined by three synapomorphies (character 40 , state 0 ; character 59 , state 0 ; character 80, state 1); all of them absent in T. garciae. An approximately square lachrymal (character 40 , state 0 ) is present in $T$. pauloensis. The other two synapomorphies, two palatoethmoid articulations (character 59, state 0), and a triserial predorsal scale pattern (character 80 , state 1 ) were not preserved and are assumed to be present in Tremembichthys species by parsimony (unambiguous). Within Cichlasomatini (sensu Kullander, 1998), Tremembichthys shares a common ancestry with Aequidens hoehnei, Laetacara flavilabris, L. thayeri, Cleithracara, Nannacara anomala and $N$. adoketa. This node is supported by five synapomorphies (characters 3, 28, 30, 78, 88), of which only the absence of the dorsal caudal fin lateral line (character 78 , state 0 ) can be verified in $T$. garciae.

The two fossil species, Tremembichthys pauloensis and T. garciae n. sp., were recovered in a sister-group relationship, supported by three synapomorphies: seven preopercular lateralis canal openings (character 47, state 0 ; this character was not preserved in T. garciae); abdominal vertebrae 14-15, the number of caudal vertebrae equal or higher (character 67, state 0 ); and three anal pterygiophores articulating with hemal $\operatorname{arch}$ (character 72, state 1). No autapomorphies were defined for Tremembichthys species.

As the analysis dealt with fossil material, and therefore a large quantity of missing characters, unresolved branches are not unexpected. Of the 91 characters listed in the matrix, $62(68 \%)$ were not informed and $15(16 \%)$ were coded as primitive states (see character states informed for both fossil species in Appendix). In this situation, the resulting tree can be considered reasonably acceptable, in view of the fact that it does not differ significantly from that based only on recent taxa (Kullander, 1998). Tremembichthys garciae new species and T. pauloensis resulted as sister species in the Cichlasomatini tribe.

\section{ACKNOWLEDGMENTS}

The authors are grateful to Maria Judite Garcia, Guarulhos and her team from the Universidade de Guarulhos, for collecting and loaning of the specimen described here. The following ones allowed us to examine specimens under their care: D. A. Campos and Rita C. Cassab (DNPM-RJ); C. del Papa (CNS) and H. S. Santos (DBAV). Suggestions and comments from two reviewers greatly improved the paper.

\section{REFERENCES}

Arratia, G. \& Cione, A.L. 1996. The fish fossil record of southern South America. Münchener Geowissenschaft Abhanlungen, 30A:9-72.

Bardack, D. 1961. New Tertiary teleosts from Argentina. American Museum Novitates, 2041:1-27.

Bedani, E.F. \& Haddad, C.F.B. 2002. Estudos preliminares de anfíbios (Anura:Pipidae) na Formação Entre-Córregos, Bacia de Aiuruoca, Terciário do Estado de Minas Gerais, Brasil. Revista Universidade Guarulhos, 6:35-42.

Casciotta, J. \& Arratia, G. 1993a. Jaws and teeth of American cichlids (Pisces:Labroidei). Journal of Morphology, 217:1-36.

Casciotta, J. \& Arratia, G. 1993b.Tertiary cichlid fishes from Argentina and reassessment of the phylogeny of New World Cichlids (Perciformes:Labroidei). Kaupia, 2:195-240.

Chakrabarty, P. 2004. Cichlid biogeography:comment and review. Fish and Fischeries, 5:97-119.

Delgado, S.G.F. \& Oliveira, M.E.B. 2004. Annonaceae e Lauraceae da Formação Entre-Córregos (Paleógeno) na bacia de Aiuruoca:implicações paleoclimáticas. Revista Brasileira de Paleontologia, 7:117-126.

Dino, R.; Garcia M.J.; Antonioli, L. \& Lima, M.R. 2006. Palinoflora das Camadas Nova Iorque, registro sedimentar do Plioceno na Bacia do Parnaíba (Maranhão). In: J.A. Perinotto; I.C. Lino; A.R. Saad; M.L. Etchebehere \& N. Morales (eds.) Boletim do VII Simpósio do Cretáceo do Brasil,UNESP, p. 42.

Garcia, M.J.; Santos, M. \& Hasui, Y. 2000. Palinologia da parte aflorante da Formação Entre-Córregos, Bacia de Aiuruoca, Terciário do Estado de Minas Gerais, Brasil. Revista Universidade Guarulhos, 5:259.

Kullander, S.O. 1983. Taxonomic studies on the percoid freshwater fish Family Cichlidae in South America. Stockolm, Swedish Museum of Natural History, 440 p.

Kullander, S.O. 1998. A phylogeny and classification of the South American Cichlid (Teleostei:Perciformes). In: L.R. Malabarba; R. Reis; R.P. Vari; Z.M. Lucena \& C.A. Lucena (eds.) Phylogeny and Classification of Neotropical Fishes, Edipucrs, p. 461498.

Lima, M.R. 1991. Estudo palinológico das "Camadas Nova Iorque", Terciário do Estado do Maranhão, Brasil. In: CONGRESSO BRASILEIRO DE PALEONTOLOGIA, 12, 1991. Boletim de Resumos, São Paulo, USP, p. 45.

Lima, M.R.; Salard-Cheboldaeff, M. \& Suguio, K. 1985. Étude palynologique de la Formation Tremembé, Tertiaire du Bassin de Taubaté (État de São Paulo, Brasil), d'aprés lês echantillons du sondage n-42 du CNP. In: D.A. Campos, C.S. Ferreira, I.M. Brito \& C.F. Viana (org.) Coletânea de Trabalhos Paleontológicos, DNPM, p. 379-393.

Lundberg, J.G.; Marshall, L.G.; Guerrero, J.; Horton, B.; Malabarba, M.C. \& Wesselingh, F. 1998. The stage for Neotropical fish diversification: A history of tropical South American rivers. In: L.R. Malabarba; R. Reis; R.P.Vari; Z.M. Lucena \& C.A. Lucena (eds.) Phylogeny and Classification of Neotropical Fishes, Edipucrs, p. 13-48.

Malabarba, M.C. 2004. On the paleoichthyofauna from the Aiuruoca Tertiary Basin, Minas Gerais State, Brazil. Ameghiniana, 
41(4):515-519.

Malabarba, M.C. \& Zuleta, O.D. Del Papa, C. 2006. Proterocara argentina, a new fossil cichlid from the Lumbrera Formation, Eocene of Argentina. Journal of Vertebrate Paleontology, 26:267275.

Oliveira, M.E.B.; Garcia, M.J. \& Fernandes, M.C.C. 2006. Folíolos e grãos de pólen de Fabales na Formação Entre-Córregos, Paleógeno da bacia de Aiuruoca, sudeste de Minas Gerais, Brasil. In: SIMPÓSIO ARGENTINO DE PALEOBOTÁNICA Y PALINOLOGIA, 13, 2006. Resúmenes, Bahía Blanca, 1:81.

Reis, R.E. \& Malabarba, L.R. 1988. Revision of the Neotropical genus Gymnogeophagus Ribeiro, 1918, with descriptions of two new species (Pisces, Perciformes). Revista Brasileira de Zoologia, 4:259-305.

Riccomini, C.; Sant'Anna, L.G. \& Ferrari, A.L. 2004. Evolução geológica do rift Continental do Sudeste do Brasil. In: V. Montesso-Neto (org.) Geologia do continente sul-americano: evolução da obra de Fernando Flavio Marques de Almeida, Ed. Beca, p. 383-405.

Santos, M. 1999. Serra da Mantiqueira e planalto do alto rio Grande: a bacia terciária de Aiuruoca e evolução morfotectônica. Universidade Estadual Paulista, Ph.D. Dissertation, 225 p.

Santos, M.; Hasui, Y.; Morales, N. \& Garcia M.J. 1999. Neotectonic control on drainage network evolution in the Aiuruoca region, southern Minas Gerais. In: S.B. Cunha \& A.J.T. Guerra (eds.) Abstracts of IAG Regional Conference on Geomorphology, IAG, p. $39-40$.
Santos, M. Hasui;Y. Morales, N. \& Ladeira, F.S.B. 2006. A Bacia Terciária de Aiuruoca: contribuição para o entendimento da Evolução Tectônica Cenozóica do Sul de Minas Gerais. In: SIMPÓSIO DO CRETÁCEO DO BRASIL, 7, 2006. Boletim, Rio Claro, UNESP, p. 114.

Schaeffer, B. 1947. Cretaceous and Tertiary actinopterygian fishes from Brazil. Bulletin of the American Museum of Natural History, 89:1-38.

Silva Santos, R. \& Oliveira, A. 1974. Considerações sobre um ciclídeo da Bacia do Paraíba, Estado de São Paulo. Anais da Academia Brasileira de Ciências, 46:699.

Silva Santos, R. \& Santos, H.S. 1993. Tremembichthys pauloensis (Schaeffer, 1947) (Pisces, Cichlidae) da Formação Tremembé, Estado de São Paulo, Brasil. Anais da Academia Brasileira de Ciências, 65:41-55.

Soria, M.F \& Alvarenga, H. 1989. Nuevos restos de mamíferos de la cuenca de Taubaté, Estado de São Paulo, Brasil. Anais da Academia Brasileira de Ciências, 61:157-175.

Stiassny, M.L. 1991. Phylogenetic intrarelationships of the family Cichlidae: an overview. In: M. Keenleyside (ed.) Cichlid Fishes: Behaviour, ecology and evolution, Chapman and Hall, p. 1-35.

Swofford, D.A. 1993. PAUP: phylogenetic analysis using parsimony Version 3.1. Champaign, Sinauer Associates.

Woodward, A.S. 1939. Tertiary fossil fishes from Maranhão, Brazil. Annals and Magazine of Natural History, Series 11, 3:450-453.

Received in February, 2008; accepted in April, 2008.

Appendix. List of character states scored for Tremembichthys garciae and T. pauloensis for the parsimony analysis presented in this paper (details in the text). Characters not listed were scored as not informed (?) for both species.

$\begin{array}{llllllllllllllllllllllllllllllll}\text { T. garciae } & 0 & 0 & 1 & ? & 1 & 1 & 0 & ? & 0 & 0 & 1 & 1 & 2 & 0 & 0 & 0 & 0 & 2 & 1 & 0 & 0 & 0 & 0 & 0 & 1 & 1 & 2 & 1 & 0 \\ T . \text { pauloensis } & 0 & ? & ? & 0 & ? & ? & 0 & 0 & ? & 0 & 1 & 1 & 2 & 0 & 0 & 0 & 0 & 2 & 1 & 0 & 0 & 0 & 0 & 0 & 1 & 1 & 2 & ? & 0\end{array}$

